\title{
A Study on the Impact of Brand Experience on Brand Attachment—Take Brand Personality as An Intermediary Variable
}

\author{
Rana Hassan \\ ESLSCA University EGYPT \\ Alaa Tarek \\ Department of Business Administration, Cairo University
}

\begin{abstract}
This research study aims to investigate if emotional brand attachment of customers can be influenced by marketing brand authenticity for cosmeceutical industry in Egypt. The research depends on a thorough literature review for the idea of brand authenticity as well as emotional brand attachment and how the first affects the latter especially on the cosmeceutical sector. The dimensions of brand authenticity adopted from literature included brand individuality, brand consistency and brand continuity. A pilot study was conducted on random respondent customers buying cosmeceuticals from multiple community pharmacies in Egypt. The aim was to investigate this relationship. Data collected show tendency towards the suggestions that brand authenticity may affect brand emotional attachment. However, it is recommended to conduct a further descriptive research to investigate the significance of this relationship.
\end{abstract}

Keywords: Brand authenticity, Brand Individuality, Brand consistency, brand continuity, emotional brand attachment, cosmecutical sector

\section{Introduction}

Brand Authenticity and brand emotional attachment are both crucial for influencing consumer purchase in all industries. Brand authenticity is not a novel construct, as it had captured the interest of many researchers since the early 2000 's. It has been defined in different ways and given multiple dimensions.

\subsection{Authenticity construct}

It is a difficult one to grasp and is important in marketing field to be able to know the consumers increasing demand for authenticity in brands as well as to get a better grasp of consumer behaviors so that marketers can affect and respond to it. Consumers interest of authentic brands is capturing the attention of researchers in marketing field (Taheri et al., 2018; Gilmore and Pine, 2007). Adding to this, the fact that customers today are more intelligent than before which emphasizes the importance of authentic brands. Customers are very doubtful towards brands, they continuously look for brands they can support and trust.

\subsection{Brand authenticity and brand selection}

In addition, brand selection is hugely depending on how authentic these brands are which means that it is not only about quality but also it is about authenticity which became prior to quality (Gilmore and Pine, 2007). Authenticity is when the brand behavior complies with what it says in order to occupy the space between what customers expect from the brand and what they actually experience. Brand loyalty and emotional attachment are awarded to brands that improve the world, and have a clear goal, or in other words are authentic.
1.3 Brand authenticity relation to organization strategic decisions

The Importance of authenticity extends to include an assessment tool for organization strategic decisions that are tailored for providing genuine products to customers (Napoli et al.2014). As marketing authenticity will allow emphasizing authentic principles to interested customers and showcase brand values and principles. Thus authenticity is of particular importance to organizations too. The researcher suggests that effective authenticity marketing can enhance emotional attachment with brands to promote trust and loyalty.

\subsection{Brand emotional attachment defined}

Some studies mentioned that emotional attachment idea revolves around bonding with experiences, locations, brands, people or objects (Arnould \& Price, 1993; Huang et al., 2017; Thomson et al., 2005; Vlachos et al., 2010). Interestingly, the higher is the attachment to a brand in an emotional way the more is the customer willing to support, and forgive mistakes of the brand (Huang et al., 2017; Levy \& Hino, 2016; Park et al., 2010). The attitude of customers towards brands is greatly affected by brand attachment which promotes customer life time value and generated more profits (Whan Park et al., 2010).

\subsection{Brand authenticity and brand emotional attachment}

In this study, the researcher suggests that brand authenticity affects the brand emotional attachment for consumers that are interested in authentic brands in the cosmeceutical industry. The researcher aims to reach results that are hopefully helpful for marketers through helping them to 
influence the brand emotional attachment through tackling brand authenticity concept.

\subsection{This research study sections}

The research starts with a comprehensive introduction about the topic and its importance, literature review explaining the brand authenticity construct and its dimensions, describing emotional brand attachment as well as the cosmeceutical industry and particularly in Egypt. Then a limited pilot study was done to establish a better understanding of the impact of brand authenticity on emotional brand attachment taking into consideration the dimensions of each construct. Then the research methodology section explains the importance of this research study theoretically and practically. Finally, the last section includes a conclusion for the whole paper and suggestions for future research.

\section{Literature Review}

In the following section we are going to discuss different definitions for the term authenticity as expressed by many researchers in literature.

\subsection{The evolution of authenticity construct}

Firstly, Authenticity was investigated by many researchers of psychology and marketing fields, however not many reached a clear explanation (Beverland, 2005). Authenticity was viewed as consisting of self-direction, consistency, reliability in the twentieth century. Afterwards Authenticity idea was doubted with the existence of multiple views of selves (see a historical review in Harter, 2002).

\subsubsection{Describing Authenticity}

Then Authenticity was explained by terms like Genuine, original, trustworthy, reliable, and real (Luthans, F. and Avolio, B. J., 2003). Molleda in 2010 and Rosado-Pinto in 2020 described authenticity as real, accountable, original and not a copy of something else (Molleda, 2010; RosadoPinto et al., 2020). To sum up all these opinions revolve around the concept of authenticity and one can conclude that authentic reflects being original, true and trusted.

\subsubsection{Brand authenticity definition}

Brand authenticity was expressed as if the brand is based on a solid internal base of honesty and capability, it has a wellknown history and strong values, then it is capable of exceeding its customer expectations (Interbrand, 2014) p.68.

\subsubsection{Indexicality and Authenticity}

However, "Indexical" was used as an indication of authenticity (Grayson and Martinec 2004). According to these authors the property of "indexicality" helps to separate original and imitation (Grayson and Martinec 2004). The suggested that that it helps to verify what is supposed to be offered through the perception of physical or behavioral facts Grayson and Martinec 2004).

\subsubsection{Consumer perception of brand authenticity}

Furthermore, brand authenticity was suggested as consumer opinion of what is original, true and genuine (Beverland, 2005; Grayson and Martinec, 2004; Southworth and Ha-
Brookshire, 2016). While, Kim and Bonn (2016) concluded that authenticity in a brand turned out to be a strong and consistent statement that is not commercial and is unique, at the same time it evolves from what the corporation believes in. Based on this one can conclude that the authenticity of a brand can be used as a non-commercial marketing message directed to interested customers.

\subsubsection{Authenticity as a brand behavior}

Authenticity was attributed to behavior in many studies. An example includes that authenticity is a comprehensive construct for both the product itself and the principles as mentioned by Coary (2013), so the author defines authenticity in the form of brand solid principles and objectives (Asuncion Hernandez-Fernandez, 2019). This explanation of authenticity is more towards defining it as a brand behavior which is not the only one as this idea was shared by Schallehn et al. (2014) and Fritz et al., (2017) who described the authenticity construct with its dimensions as will be mentioned in the brand authenticity construct section. Fritz et al. (2017) approached authenticity as brand behavior approach that is linked to constructing a uniquely original brand in an ethical frame.

\subsubsection{Authenticity between objectivity and subjectivity}

Different arguments for customer perception of authenticity was mentioned, one argument was that it is objective and the other was subjective. For instance, if consumers are given inputs to evaluate authenticity of a brand then this is an objective methodology (Beverland, 2005; Grayson and Martinec, 2004; Zhang and Merunka, 2015). So, these authors stated that brands can be evaluated in terms of authenticity dimensions by customers so it is an objective construct.

Beverland (2008) illustrated the objectivity of authenticity through explaining objective information tools that help customer evaluate authentic products such as factors that reinforce the continuation of traditional behaviors built on solid inputs.

While, others argued that perception, preferences, knowledge of a customer affect their opinion of an authentic brand and so it is a subjective methodology (Napoli et al., 2014). Adding to this point of view, Carroll and Wheaton (2009) agreed with Napoli et al. (2014) regarding the subjectivity of authenticity perception. They explained it as a societal phenomenon which is dependent on anticipations according and is not objective at all. These authors mentioned that it can be due to experiences, locations, persons, products, things and many other social aspects (Carroll and Wheaton, 2009).

One can conclude that brand authenticity perception is both objective and subjective as it may vary according to the situation, input information given to customer, knowledge, experience and individual preferences and above all the ability to assess the authenticity of a brand.

\subsubsection{Authenticity and customer self-concept}

Ryan \& Deci (2000) stated that authenticity is appreciated by customers when it matches what they do. In other words, customers evaluate the brand based on if its authenticity 
harmonizes with their actions and if so customers will probably appreciate the brand. So, if the brand matches customer self-concept then he/she would probably view it as an authentic brand in the sense that it is real and genuine to their own self.

To sum up, brand authenticity is how a brand is real, original and worth trusting, it can be due to matching target customer self-concept, it can also be due to brands aligning customer's actions. It can be both subjective and objective owing to situation. The construct of authenticity.

\subsubsection{Brand perceived authenticity}

Brand marketing communication delivered to customers was found to have a solid impact on customer opinion and understanding of authenticity (Dwivedi \& McDonald, 2018). So, marketing communications funds will be reflected on perception of brand authenticity (Dwivedi \& McDonald, 2018). It means that the more the company invests in the marketing communications directed to their target customer the more the customer will perceive their brand as authentic.

\subsubsection{Branding and authenticity}

Some researchers mentioned that branding and authenticity are related (Beverland, 2005; Brown, Kozinets, \& Sherry, 2003). Brands are significant cultural items (Holt, 2002) and have important symbolism (Belk, 1988). Authenticity can be attributed to buying patterns (Holt, 1997; Belk \& Costa, 1998; Kozinets, 2001, 2002). Brands have symbolic significance (Belk, 1988). Beverland (2005) recognized authenticity as a crucial modern marketing approach.

\subsubsection{Brand Authenticity Dimensions}

In the next section the research summarizes the literature found about dimensions of brand authenticity as mentioned by many researchers across literature.

\subsubsection{Brand authenticity explained}

The construct itself has several dimensions mentioned in literature. If the characteristic dimensions exist in the brand, then it will be recognized as authentic (Wymer \& Akbar, 2017). Dimensions are not the same for different authors; it depends on the study, research methodology and field in which the brand lies.

\subsubsection{Brand authenticity construct table}

The following table gives a comprehensive view for the dimensions studied through out literature. It illustrates authors alphabetically and shows the lack of common understanding among authors regarding authenticity dimensions. Dimensions are mentioned as they are by their corresponding authors.

Table 2.1.9.2: Shows Authenticity dimensions among different authors

\begin{tabular}{|c|c|}
\hline Research & Dimension and explanation \\
\hline $\begin{array}{l}\text { Authentic } \\
\text { Brand Index } \\
\quad(\mathbf{2 0 0 8 )}\end{array}$ & $\begin{array}{l}\text { Familiarity: commonly identified } \\
\text { Heritage and pedigree: unique traditions, related to the past, customers can relate to their past story } \\
\text { Declared beliefs brand values } \\
\text { Sincerity does not let go its principles and values } \\
\text { Personal utility customers highly depending on brand value offered } \\
\text { Originality one of a kind value offered, brand is novel and distinctive } \\
\text { Momentum increasing popularity }\end{array}$ \\
\hline $\begin{array}{l}\text { Beverland } \\
\quad(2006)\end{array}$ & $\begin{array}{l}\text { Downplaying commercial interests brand concerned far more than its financial achievement } \\
\text { Stylistic consistency doesn't tradeoff the consistency of production for trending } \\
\text { Method of production maintaining operations with dedicated skilled individuals }\end{array}$ \\
\hline Boyle (2004) & $\begin{array}{l}\text { Beautiful highlights beauty and unity } \\
\text { Honest away from unethical actions } \\
\text { Human brand sheds light on on human characteristics } \\
\text { Ethical worth trust } \\
\text { Unspun sincere, does not manipulate } \\
\text { Three dimensional provide experience that is rich } \\
\text { Sustainable future oriented } \\
\text { Simple reduces difficulties } \\
\text { Rooted connected to origin duration and location } \\
\text { Natural brand chooses natural materials and procedures }\end{array}$ \\
\hline $\begin{array}{l}\text { Bruhn et al. } \\
\text { (2012) }\end{array}$ & $\begin{array}{l}\text { Continuity historical significance, consistency, reliability and stability, keeping high quality and not carried away by } \\
\text { trends } \\
\text { Reliability trusted, keeps promises, } \\
\text { Originality one of a kind value offered, brand is novel and distinctive } \\
\text { Naturalness expresses absence of synthetics, true, and real }\end{array}$ \\
\hline $\begin{array}{l}\text { Beverland } \\
\text { (2006) }\end{array}$ & $\begin{array}{l}\text { Relationship to place linked to a unique famous place } \\
\text { Quality Commitment dedicated to high quality with no compromise }\end{array}$ \\
\hline $\begin{array}{l}\text { Beverland } \\
\text { (2009) }\end{array}$ & Quality Commitment dedicated to high quality with no compromise \\
\hline Coary (2013) & $\begin{array}{l}\text { Adhering to principles honest with customers, sticking to moral principles and mission } \\
\text { Being the category pioneer the beginner in market } \\
\text { Maintaining the original product keeping product original }\end{array}$ \\
\hline $\begin{array}{l}\text { Eggers et al. } \\
\text { (2013) }\end{array}$ & $\begin{array}{l}\text { Congruency the degree to which employee and company share compatible values and how is employees dedicated to } \\
\text { satisfy their organization values } \\
\text { Consistency commitments made to interested parties are consistent with the company's values and principles attaining } \\
\text { uniformity in brand aspects } \\
\text { Customer orientation concerned with customer's needs, fulfills and knows customer's needs, makes customization of } \\
\text { benefits for concerned parties }\end{array}$ \\
\hline
\end{tabular}




\begin{tabular}{|c|l|}
\hline $\begin{array}{c}\text { Gilmore and } \\
\text { Pine (2007) }\end{array}$ & $\begin{array}{l}\text { Three dimensional provide experience that is rich } \\
\text { Originality one of a kind value offered, brand is novel and distinctive } \\
\text { Natural: natural materials and procedures preference }\end{array}$ \\
\hline $\begin{array}{c}\text { Morhart et al. } \\
\mathbf{( 2 0 1 4}\end{array}$ & $\begin{array}{l}\text { Continuity historical significance, consistency, reliability and stability as well as timeless quality, can survive trends } \\
\text { Executing commitments } \\
\text { Symbolism what the quality of the brand represents helps customers to express their identity } \\
\text { Integrity following morals and ethics with customers, accountable, }\end{array}$ \\
\hline $\begin{array}{c}\text { Napoli et al. } \\
(\mathbf{2 0 1 4})\end{array}$ & $\begin{array}{l}\text { Sincerity does not let go its principles and values } \\
\text { Quality Commitment dedicated to high quality with no compromise } \\
\text { Napoli (2014) made a 14 component factor analysis and it was checked for three aspects of validity discriminate, } \\
\text { convergent and predictive validity (Napoli et al.2014). }\end{array}$ \\
\hline
\end{tabular}

\section{Conclusions}

The above table 2.11.1.1 shows that there were some common dimensions between different authors for example, Beverland (2006, 2009), Authentic brand index (2008) and Napoli (2014) agreed on heritage dimension. This may be true for some industries but not for others. The researcher believes that it is not suitable for the field of study in cosmeceutical products.

While Bruhn (2012) and Morhart (2014) both considered continuity a dimension of authenticity. This dimension is convincing for the researcher as being authentic is to continue being consistent in value offered. Boyle (2004); Gilmore and Pine (2007) shared the same opinion for including "Natural" aspect for authenticity. One can conclude that although true for industries but may not be applicable for others that don't depend on natural materials.

Originality was agreed upon by Authentic Brand Index (2008); Bruhn et al. (2012); Gilmore and Pine (2007). They believed that uniqueness is a source of authenticity. The researcher agrees with this opinion. Quality commitment was common in studies of Beverland (2006, 2009) and Napoli et al. (2014) both believed that brand should not compromise quality level. Sincerity was shared for both Authentic brand index (2008) and Napoli et al. (2014), while Boyle (2004); Gilmore and Pine (2007) all believed that three dimensional is an authenticity dimension.

2.1.10.3 Brand continuity, originality, reliability and naturalness as Authenticity dimensions

Bruhn et al. (2012) who described four dimensions of brand authenticity which are continuity, originality, reliability and naturalness. These authors also conducted a scale for assessing how strong is the perception of brand authenticity Bruhn et al. (2012). Additionally, these authors studied the discriminant validity for authentic constructs with concepts like brand image, satisfaction, and involvement Bruhn et al. (2012).

The author described that being stable, consistent and endure is the basis of continuity dimension Bruhn et al. (2012). While being unique, differentiated, individual, and particular is the foundation of originality dimension Bruhn et al. (2012). A brand that is trusted, sticking to what it promises customers and is credible is reliable brand Bruhn et al. (2012). Being real and genuine is the meaning of the fourth dimension of naturalness Bruhn et al. (2012). The construct is multidimensional and logical in its dimensions and explanations. However, this model did not mention if the authenticity of brand is affected by the category of products.

\subsubsection{Authenticity six dimensions' construct}

Another study for authenticity dimensions by Liao and Ma (2009) who identified six dimensions as "Heritage and persistence of style, originality, credibility, quality commitment, purity, sacredness and scarceness". This authors defined dimensions of their proposed models depending on participants answers as follows originality explained as being one of a kind, composed from natural substance and depends on the country of origin (Liao and Ma, 2009). Quality commitment as assurance for quality, credibility was explained as being honest and meeting what is expected, while heritage was defined as being consistent with traditions, uniqueness was an explanation for scarcity, sacredness was related to previous memories with high level of personal identification and involvement, and finally purity meant to be not including other substances and to concentrate on one scope or substance (Liao and Ma, 2009).

\subsubsection{Authenticity and Control willingness}

Another model was proposed by Tran (2018) who identified their model as a four dimension one. Realism is the first dimension; depending on customer understanding and building on the difference between original and copy, the authors defined it as perceiving the brand as not copied (Tran, 2018). Control is the second dimension the authors provided evidence from a study conducted by Hochschild (1983) that airline employees attempt to gain control to ensure that they are recognized as professional and skilled. Authenticity was attributed to the organization and the participants' willingness for controlling their surrounding environment (Leigh et al., 2006). Another dimension is the Connection, to connect others and their cultural identity, place, time, and society (Beverland, 2009). A sense of belonging to significant others, culture, time, location, and society (Tran, 2018). Finally, Virtue, to act morally sticking to moral principles (Beverland, 2009).

\subsubsection{Individuality, consistency and continuity effect on authenticity}

Brand individuality, brand consistency and brand continuity were all found to significantly impact the brand authenticity construct (Asuncion Hernandez-Fernandez, 2019). For each of these dimensions the authors developed a set of measurable criteria to be able to judge the dimension more accurately and to give a proper sense of what the dimension actually means. 
For instance, brand individuality included criteria previously developed by Netemeyer et al. (2004); Schallehn et al. (2014) included: The method used by brand to satisfy its promise withers very different, unique or distinct. Also, Brand consistency included criteria: brand satisfies its promise in a consistent way, current brand behavior fits to its promise, brand promise and brand action are aligned (Schallehn et al.2014).

Additionally, Brand continuity included three criteria which are if the brand had already satisfied its promise in the past, if a previous brand action fulfills its present promise and if current promise and past actions are aligned (Schallehn et al.2014). Based on these criteria the authors used a series of six criteria to evaluate brand authenticity which are Schallehn et al. (2014):

- Brand promise is according to an adopted clear philosophy

- Brand understands its mission and its promises are aligned with its personality and reason for existence

- Brand does not act against its promise or pretend to be different

- Brand expresses self-confidence and does not smooth talk with target people

- Brand changes and cops with new trends

- Brand is flexible and adapt to situations

Based on this Model, this research adopted these dimensions as they are clear, easily expressed and can be modified to easy understandable questions for customers in any field. The Brand authenticity based on this model is applicable and not complicated.

\subsubsection{The relationship between brand authenticity and emotional brand attachment}

The researcher believes that the more customers perceives a brand as an authentic brand the more he/she is going to be emotionally attached as it will be more aligned to their personality and values. The decision made by the consumers to buy the brand one more time can be an outcome of the positive brand attachment side adding to this rotating a positive recommendation about the brand (Hung \& Lu, 2018).

\subsubsection{Emotional brand attachment}

To start with, emotion is a motivator for purchasing a specific product or service according to (Berry, 2000). This author suggested that emotional customer company relationship which increasingly builds can affect brand decisions Berry, 2000). It is often referred to as long term relationship between company and customer (Dunn and Hoegg, 2014). When the customer contacts a certain brand, his/her emotional attachment is generated by the degree of the feelings sensed then (Schmalz and Orth 2012).

\subsubsection{Emotional brand attachment definition}

Attachment can be defined as a solid bond that progresses in an increasing manner with things as brands (Hung \& Lu, 2018). Bartholomew and Horowitz (1991), mentioned that humans can be emotionally attached to brands while can terminate bonds to other brands. The feeling of safety the person feels with a certain brand or product was one explanation to brand emotional bonding according to (Japutra, Ekinci, and Simkin, 2014; Main, 1999). Another meaning for emotional brand attachment was connecting to the brand according to (Schmitt, 2012).

Emotional attachment changes people perspective about the thing they are attached to so that they see it as unique and can't be replaced (Thomson, 2006). The importance of studying brand attachment can be attributed to customer devotion to the brand, trusting the brand and feeling satisfied with it (Hung \& Lu, 2018).

Adding to this, the individual - entity interactions with long term effect on the identity and personal relationship development is another definition for emotional attachment (Kinniburgh et al., 2017). Attachments were also identified as links between individuals (Vlachos et al., 2010). According to Esch et al. (2006) individuals aim to maintain a long term link with the entity they are attached to and they act towards it positively.

One can conclude that emotional brand attachment can be defined as a psychological link that is built progressively between the brand and the customer and is enriched by positive feelings of passion and affection.

\subsubsection{0 brand attachment and customer loyalty}

Furthermore, brand emotional attachment is crucial for many companies nowadays. Park et al. (2010) research findings stated that there is a link between emotional brand attachment and customer loyalty which will promote the company financially. This author expressed emotional brand attachment as the strong bond between brand and customer (Park et al., 2010). A lot of academic literature mentioned the establishment of emotional relationship between the brand and the customer (Berry, 2000; Levy \& Hino, 2016; Thomson et al., 2005). This shows the particular importance of customer brand emotional relationship in the marketing field.

\subsubsection{Cognitive and affective bonds effect on emotional attachment}

Brand attachment as a construct can be related to two dimensions according to Park et al., (2010) and Park, MacInnis, \& Priester (2006) which are cognitive bond and affective bond which links the consumer with a certain brand. This was previously mentioned by Baldwin et al. (1996) who stated that brand emotional attachment is the outcome of cognitive and emotional bonds and therefore developing brand attachment implies that customers are most likely going to act in the same way when trying the brand in future. While Bahri-Ammari (2012) suggested that Brand attachment is a long term link with brand that predicts customer relatedness to brand. It can be argued that if a brand communication strategy successfully tackled both aspects of cognition and affection then it is said to have successfully reached a deep emotional bonding with the customer which will eventually promote repurchasing decision and referral to others.

Japutra et al. (2014) and Park, MacInnis, Priester, Eisingerich, and Iacobucci (2010) and Heilbrunn (2001) all agreed that emotional brand attachment includes emotional, 
cognitive and affective bonding. Additionally, attaching to the brand is emotionally being linked to it as explained in literature (Bozzo, Merunka, \& Moulins, 2003; Lacoeuilhe \& Belaïd, 2007, Thomson et al., 2005). Thomson et al., 2005 stated that loyal customers connect with the brand expressing their passion and affection towards their brand as well as experiencing connection with it.

In addition, emotional attachment includes components of affection such as strong sentiments of affection, love and passion (Hwang et al., 2019). Similarly connection, affection and pattern were considered as a component of the emotional brand attachment construct (Thomson et al., 2005). This author stated that customers will decide to pay more for a brand they are emotionally attached (Thomson et al., 2005). Loyalty increases with emotional brand attachment (Park, MacInnis, Priester, Eisingerich, \& Iacobucci, 2010). Brand emotional attachment increases forgiveness too (Schmalz \& Orth, 2012).

\subsubsection{Brand self-connection and emotional brand attachment}

Furthermore, Chaplin and John 2005, Escalas 2004, Escalas and Bettman 2003 concluded that brand self-connection expressed as cognitive and emotional connection between the brand and the self are important dimension on brand emotional attachment. When customers consider brand as part pf their self they feel the sense of ownership and attachment.

Park et al. (2006) defined brand emotional attachment in terms of past brand attachment and forthcoming self-brand link that are already present or expected both explain the brand attachment concept. The self-brand link depends on many factors such as brand link with history, traditions, national regions, geographic regions, culture and customs.

\subsubsection{Positive and negative sides of emotional brand attachment}

However, Hung \& Lu (2018) suggested that emotional attachment to brands have both positive and negative sides. The positive side can be strengthened by succeeding in matching perceived and actual self as well as fulfilling internal enjoyment motives and self-independence (Hung \& $\mathrm{Lu}, 2018)$. On the other hand, Hung \& Lu (2018) mentioned that negative feelings of anxiety, distress and sadness stimulated from the brand can result in negative brand attachment sides.

\subsubsection{4 self-congruence effect on emotional brand attachment}

Also, some researchers concluded that the emotional brand attachment is linked to self-congruence (Huang et al., 2017; Park et al., 2010; Salimi \& Khanlari, 2018). It means that the greater the matching between actual and ideal customer self the more he/she will be emotionally bonded to the brand (Huang et al., 2017). It can be suggested that if the brand is aligned with customer's belief and how do they behave then it would reflect their actual or ideal self-concept (Mekebbaty, 2021). for a higher emotional brand bonding there must be a match between the brand identity, image, logo, design, tone and communication messages with the customer actual and ideal self-concept (Huang et al., 2017).
The Impact of Self congruence wither ideal or actual was found to have a strong effect on brand emotional bonding according to Japutra et al., (2019) which stated that selfcongruence have a direct impact on emotional bonding with the brand. For example, some skin care products replaced their perfect models with average ones moving from ideal to actual self, which created a solid emotional bond with customers who are looking for brand authenticity (Gilmore and Pine 2007).

\subsubsection{The cosmeceutical Industry}

In the following section, we are going to summarize the literature found about the cosmeceutical industry and cosmeceutical products as well as the size and growth rate of the Industry.

2.1.11.1 Cosmeceutical definition: in the late of 1970's, Albert M. Kligman was the first to promote the "Cosmeceutical" expression (R, 2002). Cosmeceutical are cosmetics with medical uses as mentioned by cosmeceutical companies. It means that they contain cosmetic ingredients as well as active ingredients with pharmaceutical effects (Brandt, Cazzaniga and Hann, 2011). Moisturizers, retinoids, anti-oxidants and depigmentation products are all examples on cosmeceutical product category (Brandt, Cazzaniga and Hann, 2011). They are used locally, and they have active pharmaceutical agents that enhance the skin and increase healthy appearance by delivering essential nutrients to it (Brandt, Cazzaniga and Hann, 2011). Cosmeceuticals are most of the time prescribed by dermatologists or derma clinics (Brandt, Cazzaniga and Hann, 2011).

Their actions may be limited to the skin only or even more deep to control skin cell functions to deliver healthy needed substances to skin, change and protect skin, regulate skin cell roles to guard against harmful conditions. The cosmeceuticals may be offered as over the counter or prescription products. Examples include products for hair, skin, oral and lip care. However, products that contain noninflammatory components and that provide skin radiation protection or anti-oxidant effects represents a lucrative opportunity in the growing cosmeceutical market (R, 2017).

2.1.11.2 Classification of cosmeceuticals according to type includes four classifications: firstly, skin cosmeceuticals includes anti-wrinkle creams, moisturizers, products to applied on the face (Rajam, Kannan, \& Kajendran, 2019). Secondly, hair cosmeceuticals which includes creams, gels, products that stimulate hair growth, medical shampoos and anti-hair loss (Rajam, Kannan, \& Kajendran, 2019). Additionally, there are medical tooth pastes, nail growth promotors and oral care products as well as medical lips tick (Rajam, Kannan, \& Kajendran, 2019).

\subsubsection{Cosmeceutical sector}

The cosmeceutical market sector is the largest growing in the cosmeceutical and personal care industry (Yaoa, Wenb, \& Wenc, 2018). The cosmeceutical market is a highly competitive market. The market size of cosmeceutical products is growing due to factors such as innovation of active ingredients, advanced nanotechnology, and plant stem cell technology ( $R$, 2017). The market was evaluated as more than 24 billion dollars in in 2004 while it increased to 
30 billion dollars in 2011 according to market reports (Yaoa, Wenb, \& Wenc, 2018).49.5 billion USD was the cosmeceutical sector value worth in 2018, and it was anticipated to continue growing (Global Cosmeceutical Market Size \& Share Report, 2019-2025, 2021).

However, although cosmeceutical expression is the newly used expression by many skin care companies but FDA still not convinced with it and regards it as a new marketing way for cosmetics that is smart enough for the new savvy consumers (J, R, \& N, 2012).

\subsubsection{Factors that led to the rise of the Cosmeceutical industry}

Many factors led to the rise of cosmeceutical products sector. For instance, physical appearance is becoming more as an issue of concern to people, also shifting from synthetic to more organic products increasing the need of cosmeceuticals (Global Cosmeceutical Market Size \& Share Report, 2019-2025, 2021). Although some researcher mentioned that looking and feeling beautiful had always been a human thing as well as to look healthy and nice (Rajam, Kannan, \& Kajendran, 2019).

The increasing demand can also be attributed to the promoted skin care awareness among Asian and American women owing to their commonly known sensitive skin (Global Cosmeceutical Market Size \& Share Report, 2019$2025,2021)$. These women are composing a large target market demanding products with characteristics such as antiinflammatory, antibacterial, antiseptic and moisturizing (Global Cosmeceutical Market Size \& Share Report, 20192025 , 2021). Hence the need for cosmetic products with pharmaceutical action is increasing.

Another reason was the ageing population which seek young and beautiful look through innovative products. Also, the Millennials and middle aged population are suffering fear from ageing due to the high rates of ageing signs incidence all of these factors led to the rising need for effective cosmeceuticals Global Cosmeceutical Market Size \& Share Report, 2019-2025, 2021). Adding to this the rising concern about skin conditions fueled by the environmental change, and stressful life styles positively influenced the cosmeceutical skin care products sales Global Cosmeceutical Market Size \& Share Report, 2019-2025, 2021).

\subsubsection{Generations seeking cosmeceutical products}

Two generations were found to be keen about their physical appearance which were baby boomers and middle aged populations $(R, 2017)$. On the other hand, the fear from harmful ingredients that may be incorporated in cosmeceuticals may hinder the growth of the cosmeceutical industry $(\mathrm{R}, 2017)$. The federal trade commission is responsible for controlling the industry with respect to validity promoted in advertisements. Promoting skin care among Asian and American women owing to their common sensitive skin condition among them.

\subsubsection{Brand authenticity in the cosmeceutical industry}

Brand authenticity is very important in cosmeceutical industry as these products are used directly on the body; customers need to feel authenticity in the product and in the feedback. Customers are now less likely to be tricked with the influencer video content marketing everything is clear and visible and it becomes less likely to be faked.

Authenticity Marketing in the cosmeceutical industry is becoming more popular in the cosmetic industry, such as accepting the natural look in a new trend (Lyons, 2021). It is the most promising section of the personal care industry $(\mathrm{C}$, 2005).

Real faces are used in marketing campaign away from over processed fake photos that were used in the past days which enforces the idea of authenticity (Lyons, 2021). The idea of promoting authentic beauty gives customers a story that they can relate too, they feel the models look similar to them and so they believe in the brand and become emotionally attached to it. Influencers recommending the cosmeceutical products are featuring photos in the morning, or even at home that gives a sense of authenticity in a setting similar to the day to day life of the target audience.

Authenticity can be seen in the No-make up make-up looks for the cosmeceutical brand models used in the campaigns. Using different hair styles. Life style models all expressing the target audience persona are all examples of authenticity marketing. Additionally, some brands, adopt the idea of asking women causal questions about work, life, kids and even how they launched their businesses. Women in these ads look absolutely ordinary to embrace the authenticity and assure it.

\subsubsection{The cosmeceutical Industry in Egypt}

The cosmeceutical market in Egypt is a subset of the cosmetics market which is witnessed to be booming in the last year. This change is attributed to differences in way of living and the increasing demand of customer to promote their physical appearance. The increased awareness about the dangers of chemicals caused a shift towards natural cosmeceuticals away from synthetic cosmetics. However, natural herbal cosmetics are the new trends starting in Egypt currently.

Based on the above literature, there is a need to investigate the effect of brand authenticity on emotional brand attachment into a conceptual model.

\subsection{Pilot study}

In-depth interviews were conducted with 51 customers who visited different community pharmacies, questions covering the previously suggested hypotheses were asked. All questions asked to the respondents were exactly the same, answers were summarized, contrasted and categorized to get a brief idea about the validity of the suggested conceptual model.

First of all, for the brand authenticity construct, some questions were introduced about if they really care about the fact that there regularly purchased brand is real, or original, as a result few respondents stated that they are not that interested about product originality as long as it gives them the value they are seeking. Some added that that they 
purchase the product as they are used to it through the years, one even said" I am used to it" when asked about reason for purchasing.

Large number of respondents mentioned that they care about brand uniqueness when asked questions to assess their understanding of authenticity in cosmeceutical products. Some respondents believed that they favor their cosmeceutical product choice as it was unique, some expressed it as "One of a kind". Additionally, large number of respondents described that their brand was original and that it was the reason why they love it and purchase it. However, few attributed this to its country of origin. While some thought that its uniqueness comes from its continuing quality throughout the years.

However, a small number of respondents thought that the reason they purchase the product was related to the fact that the brand supports good actions and this is aligned with their personality some answered phrases like "I feel it suits me" and "it represents me" were used.

One can conclude that, if the cosmeceutical brand actions are aligned with their target segment personality, then an emotional attachment between the brand and customer is most likely to develop. But this may need further investigation to make sure if that is true or depends on personality.

When asked about if the cosmeceutical brand has been always satisfying its promise from the past to date almost all respondents stated that "they do not remember but they think so" All these respondents expressed directly or indirectly that this is the reason they believe that it attaches them to their brand affectively.

For example, almost large number of respondents mentioned that they purchase their favorite antiaging cosmeceutical cream as it uniqueness comes from the fact that it gives them the required effect they are looking for and that is the reason they are purchasing it and will continue on purchasing. This suggests that brand authenticity affects cognitive dimension of brand attachment in the tested respondents.

One can conclude that, brand individuality, brand consistency and continuity all affect emotional brand attachment. The more prominent relation was that of brand individuality and emotional bonding. Among all antecedents of emotional brand attachment, the most noticed were brand emotional bonding and brand affective bonding more than brand cognitive bonding when authenticity was emphasized. This suggests that in this limited pilot study there is a relation between brand authenticity and brand emotional attachment.

Interestingly, most of the males who were using the brand was just because they are used to it as mentioned when asked why they think their brand is unique, however most of the females were cognitively bonded to their brand for reasons related to its effect which suggests that gender differences can be another factor in the brand authenticity and brand emotional attachment relationship. However, it's not know if this is related to personality and culture or not so it is recommended to investigate this aspect in future research.

Based on this pilot study, the final variable of brand authenticity is individuality, consistency and continuity while dimensions of brand emotional attachment are cognitive and affective bonding.

\subsection{Structure of the conducted interviews}

a) The first section of the questionnaire was about demographic characteristics of the sample such as age and gender

b) The following question asked was "How often do you purchase cosmeceutical products?" answers were: Never, sometimes (2 times per month), always (more than 4 times a month) if the respondent choses never then he was not allowed to finish the interview to eliminate irrelevant respondents

c) The following section contained questions to address the hypotheses suggested

- Do you believe that your favorite cosmeceutical brand is unique?

- How do you think that your brand uniqueness makes you feel emotionally attached to your brand?

- How much do you think that your brand uniqueness makes you like it?

- How much do you think that your brand uniqueness makes you trust your brand?

- How much do you think that you purchase your brand do you to its uniqueness?

- Do you think that your favorite brand actions are consistent with its personality?

- Do you think that your favorite brand consistency is the reason you like it?

- How much do you think that you are emotionally attached to your brand as it has a continued fulfilling for its promise?

\section{Research Methodology}

\subsection{The research problem}

This research aimed at investigating the effect of brand authenticity on emotional brand attachment in the cosmeceutical sector in Egypt

3.2 The research objective is to find the effect of authenticity on building brand emotional attachment which would eventually lead to trust, brand love as well as repurchase intension as mentioned by literature.

- This research is adding to the academic literature of brand authenticity effect on emotional brand attachment by studying the cosmeceutical sector.

- This research is intended to provide guidance to marketers in the field so that they can tackle the construct of authenticity to affect the brand emotional attachment intended to increase trust and loyalty among the cosmeceutical industry products.

\subsection{The research importance}


- The importance of the research idea comes from the research gap and the fact that there had been a significant lack of research regarding the impact of brand authenticity on emotional brand attachment particularly in the cosmeceutical industry.

- The study is very important in understanding how to use brand authenticity to enrich brand emotional attachment which leads to loyalty, a positive word of mouth and most likely repurchasing intention.

\subsubsection{Theoretical implications}

- The research aims at contributing to the literature of brand authenticity effect on emotional brand attachment in the cosmeceutical sector.

- This is particularly helpful as nothing comprehensive was mentioned about this particular industry regarding the investigated variables.

\subsubsection{Practical implications}

On practical level, this research can be used to aid marketers in manipulating brand emotional attachment through marketing authenticity.

- This helps to nurture brand trust and loyalty.

- Companies can use this study to decide if their strategies in marketing authenticity are effective or not or maybe need further adjustment depending on the insights of the limited pilot study done.
- The research helps managers by giving an idea about the importance of marketing authenticity of cosmeceutical products to increase customers purchase intention in the cosmeceutical sector.

\subsubsection{Hypotheses}

H1: Brand individuality positively affect brand emotional bonding.

H2: Brand individuality can affect brand cognitive bonding positively

H3: Brand individuality can affect brand affective bonding

H4: Brand consistency affects emotional bonding positively

H5: Brand consistency affects cognitive bonding positively

H6: Brand consistency affects affective bonding positively

H7: Brand continuity affects emotional bonding positively

H8: Brand continuity affects cognitive bonding positively

H9: Brand continuity affects affective bonding positively

H10: Brand Authenticity affects brand emotional attachment

\subsubsection{Research variables}

This research studies the independent variable which is the brand authenticity having its antecedents which are brand individuality, brand consistency and brand continuity. While, dependent variable is the brand emotional attachment with its antecedents affective and cognitive bonding

\subsubsection{Research Conceptual model}

\subsubsection{Research population and sampling unit}

The research populations are the millennial population in Egypt using the cosmeceutical products as literature mentioned that these age groups are interested in authenticity among purchased products. However, the sampling units are people purchasing cosmeceutical brands from community pharmacies, those ordering cosmeceuticals from community pharmacies and those purchasing it from pharmacy by themselves.

\subsubsection{Research limitations}

\subsubsection{Methodological limitations}

This research study did not include any descriptive statistical analysis and no empirical data was included.

\subsubsection{Financial limitations}

The research did not have enough resources to expand the pilot study into a larger number of respondents, so it cannot be generalized and it was limited Egyptian customers.

\subsubsection{Time limitations}

There was no enough time to investigate the impact of gender differences, personality differences or sub-culture differences on brand authenticity and brand emotional attachment relationship.

\section{Conclusions and Implications for Further Research}

\subsection{Conclusion}

To begin with, it seems that the literature and pilot study suggest that communicating authenticity might be important in the sense that brands need to express their authentic identity without imitating others and understand the reason of their existence in order to create an emotional attachment with target customer. Especially, in current times where customer is increasing looking for authentic brands. Hence, emotional brand attachment can result in trust and loyalty. Although it is still recommended to conduct further descriptive tests to examine this hypothesis empirically.

This research included dimensions of individuality, consistency and continuity as it is believed to be the most suitable for cosmeceutical industry and target customer, also these dimensions were feasible within the time limits of the study. Also, the dimensions of cognitive and affective bonding were selected for brand emotional attachment as they were commonly agreed upon by many scientists in literature. 
According to the research paper, regarding brand authenticity, it seems that brand selection might be a result of the value offered or due to regular habitual purchase. Other brand selections can be due to caring about different dimensions of authenticity as mentioned in the following section.

\section{Brand individuality positively affect brand emotional attachment}

For Brand individuality, and according to pilot study, it might be concluded that brand individuality and brand emotional attachment might be correlated in a positive way, so uniqueness can be a reason for a positive emotional bonding with target customer. Some reasons suggested may be related to country of origin or the value they get which suggests the existence of cognitive bonding while others just didn't have a clear reason which suggests emotional bonding existence. However, it is highly recommended test this correlation empirically with a descriptive research.

\section{Brand consistency affects cognitive bonding positively}

Regarding brand consistency impact, it appears that the data is inclined towards that brand actions consistency positively impacts the dimension of cognitive bonding in brand emotional attachment construct. Possibly by aligning brand actions with brand personality as well as target customer personality If customers can evaluate this relationship clearly then it is suggested that consistency affects cognitive bonding. Although, this may imply the need for a descriptive research to further test this relationship.

\section{Brand consistency affects emotional bonding positively}

Adding to brand consistency impact, the Pilot study data may suggest that some customers feel that the brand suits them and their personality. Therefore, it might be concluded brand consistency can affect emotional bonding. However, they are not able to give a clear reason for this. This hypothesis further descriptive testing.

\section{Brand continuity affects emotional bonding positively}

Regarding brand continuity, the data tends to show that brand continuity may affect emotional bonding dimension of emotional brand attachment; this can be attributed to the feeling of trust built throughout the years as well as building a brand name through the years. However, it is still suggested to conduct a further descriptive investigation to know the nature of this relationship.

\section{Brand continuity affects cognitive bonding positively}

Further research is suggested to know if this hypothesis is valid or not as the limited pilot study did not show any clear findings regarding it.

\section{Brand Authenticity affects brand emotional attachment} Furthermore, regarding authenticity impact on brand emotional attachment, the pilot study and literature mentioned above suggest the high importance of tackling the aspects of individuality in value offered, continuity and consistency aspects of brand authenticity to promote consumers cognitive or affective bonding with the brand or both. These finding is most likely emphasizing the importance of this relationship in enriching brand loyalty and trust. If Marketers used the brand authenticity concept they are probably going to enhance attachment and therefore there will be a possible increase in repurchasing intention increasing the customer life time value with the brands.

So, some marketers are overlooking the importance of brand authenticity. This research helps to provide a roadmap for them for more creative solutions to enhance customer emotional brand attachment. This will likely increase the customer positive word of mouth for the brand based on a solid foundation of emotional attachment.

Finally, it might be concluded that brand authenticity is increasingly becoming an important component of the branding process. This is because uniqueness, originality, consistency and continuity can help enrich the branding of a certain cosmeceutical product. It can also help in positioning the brand as symbol of uniqueness and exceptional quality, and so becomes an important helpful factor in brand selection criteria.

\subsection{Implications for further research}

Empirical statistics and statistical analysis are still needed for further investigation of this study findings regarding the relationship studied. The research was applied to the cosmeceutical sector. However, it is recommended to apply it on other industry sectors. This research included the study on Egyptian customers of cosmeceutical brands, it is suggested to apply it indifferent countries to enrich the literature with the significance of this relationship.

\section{References}

[1] Arnould, E.J.and Price, L.L.(1993) River Magic: Extraordinary Experience and the Extended Service Encounter. Journal of Consumer Research, 20, 24-45. http://dx.doi.org/10.1086/209331

[2] Asuncion Hernandez-Fernandez, M.C.(2019).Brand authenticity leads to perceived value and brand trust. European Journal of Management and Business Economics, 222-238.

[3] Bahri-Ammari N.(2012).The effects of loyalty program quality on word-of-mouth recommendations intentions. World Academy of Science, Engineering and Technology, 6 (4), 619-628

[4] Baldwin, M.W., Patrick, J., Keelan, R., Fehr, B., Enns, V., \& Koh-Rangarajoo, E.(1996).Social-cognitive conceptualization of attachment working models: Availability and accessibility effects. Journal of Personality and Social Psychology, 71 (1), 94-109.

[5] Bartholomew, K., \& Horowitz, L.M.(1991).Attachment styles among young adults: A test of a four-category model. Journal of Personality and Social Psychology, 61 (2), 226-244

[6] Belk, R., 1988.Possessions and the Extended Self. Journal of Consumer Research, 15 (2), p.139.

[7] Belk, Russell W.and Janeen Arnold Costa (1998), "The Mountain Myth: A Contemporary Consuming Fantasy, " Journal of Consumer Research, 25 (December), 218-40

[8] Berry, L., 2000.Cultivating Service Brand Equity. Journal of the Academy of Marketing Science, 28 (1), pp.128-137. 
[9] Beverland, M.B.(2005), "Crafting brand authenticity: the case of luxury wines", Journal of Management Studies, Vol.42 No.5, pp.1003-1029.

[10] Beverland, M.B., Lindgreen, A. and Vink, M.W.(2008), "Projecting authenticity through advertising: consumer judgments of advertisers' claims", Journal of Advertising, Vol.37 No.1, pp.5-15.

[11] Beverland, M.B.(2009).Building brand authenticity: 7 habits of iconic brands. London, UK: Palgrave Macmillan.https://doi_org/10.1057/9780230250802.

[12] Bozzo, C., Merunka, D., \& Moulins, J.L.(2003). Fidélite ét comportement d'achat: Ne pas se fier aux apparences (Fidelity and behavior of purchase: Do not be fooled by appearances).Decisions Marketing, 32 (4), 9-17.

[13] Brown, S., Kozinets, R.and Sherry, J., 2003.Teaching Old Brands New Tricks: Retro Branding and the Revival of Brand Meaning. Journal of Marketing, 67 (3), pp.19-33.

[14] Brandt, F., Cazzaniga, A. and Hann, M., 2011.Cosmeceuticals: Current Trends and Market Analysis. Seminars in Cutaneous Medicine and Surgery, 30 (3), pp.141-143.

[15] Bruhn, M., Schoenmüller, V., Schäfer, D., \& Heinrich, D.(2012).Brand authenticity: Towards a deeper understanding of its conceptualization and measurement. Advances in Consumer Research, 40, 567-576.

[16] Carroll, G.R.and Wheaton, D.R., 2009.The organizational construction of authenticity: An examination of contemporary food and dining in the US. Research in Organizational Behavior, 29, pp.255282.https://www.sciencedirect.com/science/article/pii/ S0191308509000070

[17] Coary, S.P.(2013), "Scale construction and effects of brand authenticity", ABI/INFORM Complete, available

at:

http://search.proquest.com.liblink.uncw.edu (accessed July 8, 2016).

[18] Chaplin, Nguyen, and John, Deborah Roedder (2005), "The Development of Self-Brand Connections in Children and Adolescents, "Journal of Consumer Research, 32 (1), 119-29.

[19] Dunn, L.and Hoegg, J.(2014), "The impact of fear on emotional brand attachment", Journal of Consumer Research, Vol.41 No.1, pp.152-168

[20] Dwivedi, A.and McDonald, R.(2018), "Building brand authenticity in fast-moving consumer goods via consumer perceptions of brand marketing communications", European Journal of Marketing, Vol.52 No.7/8, pp.13871411.https://doi_org/10.1108/EJM-11-2016-0665

[21] EL Mekebbaty, M.M.A.(2021).The Effect of Brand Authenticity towards Emotional Brand Attachment: The Moderating Role of Brand Image. Scientific Journal for Financial and Commercial Studies and Researches (SJFCSR), Vol.2 (1) Part1.pp.340-383.

[22] Escalas, Jennifer E.(2004), "Narrative Processing: Building Consumer Connections to Brands, "Journal of Consumer Psychology, 14 (1-2), 168-79.

[23] Esch, F., Langner, T., Schmitt, B.and Geus, P.(2006), "Are brands forever? How brand knowledge and relationships affect current and future purchases",
Journal of Product and Brand Management, Vol.15 No.2, pp.98-105.

[24] Fine, G.A.(2003).Crafting authenticity: The validation of identity in self-taught art. Theory and Society, 32 (2), 153-180.

[25] Fritz, K., Schoenmueller, V. and Bruhn, M.(2017), "Authenticity in branding exploring antecedents and consequences of brand authenticity", European Journal of Marketing, Vol.51 No.2, pp.324-348

[26] Grace R, Cosmeceutical: Functional food for the skin. Natural foods merchandiser, 2002; 23: 92-99.

[27] Gilmore, J.H., \& Pine, B.J.(2007).Authenticity: what consumers really want. Harvard Business School Press.

[28] Grandviewresearch.com.2021.Global Cosmeceutical Market Size \& Share Report, 2019-2025.[online] Available <https://www.grandviewresearch.com/industryanalysis/cosmeceutical-market\#: text=The $\% 20$ global $\% 20$ cosmeceutical $\% 20$ market $\% 20$ size $\% 20$ was $\% 20$ valued $\% 20$ at, consciousness $\% 20$ of $\% 20$ the $\% 20$ consumers $\% 20$ about $\% 20$ their\%20physical\%20appearance.> [Accessed 15 August 2021].

[29] Grayson, K.and Martinec, R.(2004), “Consumer perceptions of iconicity and indexicality and their influence on assessments of authentic market offerings", Journal of Consumer Research, Vol.31 No.2, pp.296-312.

[30] Guèvremont, A.(2018).Creating and interpreting brand authenticity:

The case of a young brand.Journal of Consumer Behaviour, $17 \quad$ (6), 505-518 Guèvremont, A., \& Grohmann, B.(2016).The brand authenticity effect: situational and individual-level moderators. European Journal Marketing, 50 (3-4), 602-620

[31] Harter, S.(2002). Authenticity. In C.R.Snyder, \& S.J.Lopez (Eds.), Handbook of Positive Psychology (pp.382-394).New York: Oxford University Press.

[32] Heilbrunn, B.(2001).Les facteursd' attachement du consommateur à la marque (Factors of consumer attachment to the brand).Thèse de Doctorat a Sciences de Gestion (Thesis of doctorate in sciences of management).Paris: Université Paris-Dauphine.

[33] Hochschild, A.R.(1983).The managed heart: Commercialization of human feeling. Berkeley, CA: University of California Press.

[34] Holt, D.(1997).Poststructuralist Lifestyle Analysis: Conceptualizing the Social Patterning of Consumption in Postmodernity. Journal of Consumer Research, 23 (4), 326.doi: 10.1086/209487

[35] Holt, D.B.(2002), "Why do brands cause trouble? a dialectical theory of consumer culture and branding", Journal of Consumer Research, Vol.29, June, pp.7090.

[36] Huang, Z.(Joy), Zhang, C., \& Hu, J.(2017).Destination brand personality and destination brand attachment-the involvement of self-congruence. Journal of Travel and Tourism Marketing, 34 (9), 1198-1210.

[37] Hung, H.-Y., \& Lu, H.-T.(2018, March 30).The rosy side and the blue side of emotional brand attachment. 
Journal of consumer behaviour: An international research review, 17 (3), 302-312.

[38] Interbrand (2014), "Best retail brands publication", Interbrand, available at: http://interbrand.com (accessed February 5, 2016).

[39] J, A.B., R, N., \& N, R.(2012, February).A Comprehensive Review of Consumption Pattern and strategies in cosmeceutical market with a focus on dermaceuticals in Indian market. International Journal of Scientific and Research Publications, 2 (2), 171180.

[40] Japutra, A., Ekinci, Y., \& Simkin, L.(2019).Selfcongruence, brand attachment, and compulsive buying. Journal of Business Research, 99 (November 2016), 456-463.

[41] Japutra, A., Ekinci, Y., \& Simkin, L.(2014).Exploring brand attachment, its determinants and outcomes. Journal of Strategic Marketing, 22 (7).doi: 10.1080/0965254X.2014.914062

[42] Kim, H.and Bonn, M.A.(2016), “Authenticity: do tourist perceptions of winery experiences affect behavioral intentions?", International Journal of Contemporary Hospitality Management, Vol.28 No.4, pp.839-859.

[43] Kozinets, R.V.(2001).Utopian enterprise: Articulating the meanings of Star Trek's culture of consumption. Journal of Consumer Research, 28 (1), 67-88.

[44] Kozinets, R.V.(2002).Can consumers escape the market? Emancipatory illuminations from Burning Man.Journal of Consumer Research, 29 (1), 20-38.

[45] Kinniburgh, K.J., Blaustein, M., Spinazzola, J.and Van der Kolk, B.A.(2017), "Attachment, self-regulation, and competency: a comprehensive intervention framework for children with complex trauma", Psychiatric Annals, Vol.35 No.5, pp.424-430.

[46] Lacoeuilhe, J., \& Belaïd, S.(2007). What measure (s) for brand attachment? French Review of Marketing, $213(3 / 5), 7-25$

[47] Levy, S., \& Hino, H.(2016).Emotional brand attachment: a factor in customer-bank relationships. International Journal of Bank

[48] Liao, S., \& Ma, Y.Y.(2009).Conceptualizing consumer need for authenticity. International Journal of Business and Information, 4 (1), 89-114.

[49] Luthans, F.and Avolio, B.J.(2003) Authentic Leadership: A Positive Developmental Approach. In: Cameron, K.S., Dutton, J.E.and Quinn, R.E., Eds., Positive Organizational Scholarship, Barrett-Koehler, San Francisco, 241-261

[50] Lyons, J.(2021, March 4).Retrieved from Constant contact: https://blogs.constantcontact.com/marketingin-the-beauty-industry/

[51] Main, M.(1999). Epilogue. Attachment theory: Eighteen points with suggestions for future studies. In J. Cassidy \& P. R. Shaver (Eds.), Handbook of attachment: Theory, research and clinical applications (pp.845-887).New York, NY: The Guilford Press

[52] Mekebbaty, M.M.(2021, January).The Effect of Brand Authenticity Toward Emotional Brand. Scientific Journal for Financial and Commercial, 2, 340-383.

[53] Molleda, J. (2010), "Authenticity and the construct's dimensions in public relations and communication research", Journal of Communication Management,
Vol.14

No.3,

pp. $223-236$.

https://doi_org/10.1108/13632541011064508.

[54] Moulard, J.G., Raggio, R.D.and Folse, J.A.G.(2016), "Brand authenticity: testing the antecedents and outcomes of brand management's passion for its products", Psychology and Marketing, Vol.33 No.6, pp.421-430.

[55] Napoli, J., Dickinson, S.J., Beverland, M.B.and Farrelly, F.(2014), "Measuring consumer-based brand authenticity", Journal of Business Research, Vol.67 No.6, pp.1090-1098.

[56] Oh, Hyunjoo \& Prado, Paulo \& Korelo, Jose Carlos \& Frizzo, Francielle.(2019).The effect of brand authenticity on consumer-brand relationships. Journal of Product \& Brand Management.28.10.1108/JPBM09-2017-156.

[57] Park, C.W., MacInnis, D.J., \& Priester, J.(2006).Beyond attitudes: Attachment and consumer behavior. Seoul National Journal, 12 (2), 3-36.

[58] Park, C., MacInnis, D.J., Priester, J., Eisingerich, A.B., \& Iacobucci, D.(2010).Brand attachment and brand attitude strength: Conceptual and empirical differentiation of two critical brand equity drivers. Journal of Marketing, 74 (6), 1- 17.

[59] Rajam, R.P., Kannan, S., \& Kajendran, D.(2019, october). Cosmeceuticals an Emerging Technology A Review. World Journal of pharmaceutical research, 8 (12), 664-685.

[60] R, A., 2017.Cosmeceuticals Market-Industry Analysis, Size, Share, Growth, Trends and Forecast to 2024.[online] Egypt-business.com. Available at: $<$ https://www.egypt-

business.com/brochure/details/1717-cosmeceuticalsmarket---industry-analysis-size-share-growth-trendsand-forecast-to-2024/104662> [Accessed 5 August 2021].

[61] Ryan, R.M., \& Deci, E.L.(2000).Self-determination theory and the facilitation of intrinsic motivation, social development, and well-being. American Psychologist, 55 (1), 68-78.

[62] Rosado-Pinto, F., Loureiro, S.M.C., \& Bilro, R.G.(2020).How Brand authenticity and Consumer Brand Engagement Can Be Expressed in Reviews: A Text Mining Approach. Journal of Promotion Management, 26 (4), 457-480.

[63] Salimi, M., \& Khanlari, A.(2018).Congruence Between Self-Concept and Brand Personality, Its Effect on Brand Emotional Attachment. Academy of Marketing Studies Journal, 22 (4), 1-21

[64] Schmalz, S. and Orth, U., 2012.Brand Attachment and Consumer Emotional Response to Unethical Firm Behavior. Psychology \& Marketing, 29 (11), pp.869884.

[65] Schallehn, M., Burmann, C.and Riley, N.(2014), "Brand authenticity: model development and empirical testing", The Journal of Product and Brand Management, Vol.23 No.3, pp.192-199.

[66] Southworth, S.S., \& Ha-Brookshire, J.(2016).The impact of cultural authenticity on brand uniqueness and willingness to try: The case of Chinese brands and US consumers. Asia Pacific Journal of Marketing and Logistics, 28 (4), 724-742. 
[67] Southworth, S.S.and Ha-Brookshire, J.(2016) The Impact of Cultural Authenticity on Brand Uniqueness and Willingness to Try. Asia Pacific Journal of Marketing and Logistics, 28, 724742.https://doi.org/10.1108/APJML-11-2015-0174

[68] Taheri, B., Farrington, T., Curran, R.and O'Gorman, K.(2018), "Sustainability and the authentic experience.Harnessing brand heritage-a study from Japan", Journal of Sustainable Tourism, Vol.26 Nozwdser4w3d 1, pp.49-67.

[69] Thomson, M., MacInnis, D.J., \& Park, C.W.(2005).The ties that bind: Measuring the strength of consumers' emotional attachments to brands. Journal of Consumer Psychology, 15 (1), 77-91.

[70] Thomson, M.(2006).Human brands: Investigating antecedents to consumers' strong attachments to celebrities. Journal of Marketing, 70 (3), 104- 119.

[71] Thornfeldt C, Cosmeceticals containing herbs: fact, fiction, and future, Dermatol Surg, July 31, 2005; 87380.

[72] Vlachos, P.A., Theotokis, A., Pramatari, K., \& Vrechopoulos, A.(2010).Consumer-retailer emotional attachment: Some antecedents and the moderating role of attachment anxiety. European Journal of Marketing, 44 (9), 1478-1499.

[73] Whan Park, C., Macinniss, D.J., Priester, J., Eisingerich, A.B., \& Iacobucci, D.(2010).Brand attachment and brand attitude strength: Conceptual and empirical differentiation of two critical brand equity drivers.Journal of Marketing, 74 (6), 1-17.Volume https://doi_org/10.1509/jmkg.74.6.1

[74] Wymer, W., \& Akbar, M.M.(2017, february 22).Brand authenticity, its conceptualization, and its relevance to nonprofit marketing. International Review on Public and Nonprofit Marketing, 14, 1-16.

[75] Yaoa, Y., Wenb, Y.-F., \& Wenc, G.(2018, June).A Study on The Characteristics of Logistics System of Taiwan's Cosmeceutical Industry. International Journal of Pharmaceutical Science Invention, 7 (6), 28-36.

[76] Zhang, M.and Merunka, D.(2015), "The impact of territory of origin on product authenticity perceptions: an empirical analysis in China", Asia Pacific Journal of Marketing and Logistics, Vol.27 No.3, pp.385-405.

[77] Tran, V.(2018). The Brand Authenticity Scale: Development and Validation. Contemporary Management Research, 14 (4), 277-291.doi: 10.7903/cmr.18581 